\title{
Increasing Geographic Literacy through the Development of Computer Supported Collaborative Learning
}

\author{
https://doi.org/10.3991/ijet.v15i07.13255
}

Neni Wahyuningtyas, Idris $(\bowtie)$

Universitas Negeri Malang, Malang, Indonesia

idris.fiseum.ac.id

\begin{abstract}
This paper aims to develop computer supported collaborative learning to improve geographic literacy. This study used research and development with the ASSURE model. The results of this development are in the form of basic geography concept modules with 3 videos integrated into elearning. The media and material validation show that the product developed was very good and worth testing. In addition, the results of media validation by taking into account indicators of attractiveness, efficiency and effectiveness, were declared very good and students were enthusiastic about learning to use this media. This product can be an alternative medium for the 21 st century learning environment that applies e-learning in the learning process.
\end{abstract}

Keywords - Geographic literacy, CSCL, e-learning, module, videos.

\section{Introduction}

The integration of information and communication technology (ICT) in learning has become a new platform in the learning process for decades [1], [2]. ICT has enabled educators face to face without space and time limits [3]. The utilization of ICT in learning has also been proven to improve communication and collaboration skills between students [4], leadership skill [5] [8], and student's motivation [9]. In addition, some literature has confirmed that learning success is largely determined by individuals, instructors, institutions, courses, and the environment [10] [12]. Therefore, integrating the use of information technology in learning becomes urgent to provide a fun way of learning and also to form an effective learning environment.

Computer Supported Collaborative Learning (CSCL) is one of the learning approaches that is interesting and relevant to the concept of modern learning which has a paradigm that educators are not as people who transfer knowledge but as facilitators and motivators. The development of this model is based on the concept of serving individual characteristics and collaboration [13]. CSCL allows students to study independently. Xinyu [14] explains that CSCL is collaborative learning in which a group of students is in a computer network in order to maximize individual, team and learning outcomes to achieve goals through discussion and useful assistance. The 
meaning of knowledge gained in learning is not only obtained directly from educators or information in the system. However, the meaning that is built depends on the prior student's cognitive structure (prior knowledge) of each individual and it is personal.

Universitas Negeri Malang (UM) as the learning university has a meaning as a learning organization. UM's organizational systems prioritize aspirations, care development, and capability development. As a learning resource, UM plays the role of learning resource, place of learning, learning media, and learning references for all. In addition, at present, UM is designated as a center of excellence in learning innovation by the IDB (Islamic Development Bank) to strengthen the nation's competitiveness. By developing learning innovations, UM will be used as a reference for national education. As a form of actualizing the development of this learning innovation, UM is committed to developing a life-based learning curriculum.

The development of this life-based learning curriculum, of course, was initiated as a step to welcome various changes and challenges of the Industrial Revolution 4.0. The Industrial Revolution 4.0 has tremendous potential in overhauling the industry and changing various aspects of human life. With various challenges and changes, there needs to be a real reconstruction of mindset and action in order to develop in learning.

One of the study materials in social studies learning that needs to be developed is geography. The facts show that students and educators have minimal understanding of geographical literacy. Learning geography at this time takes place only limited to factual and conceptual exposure, without being able to study how the relationships created with each other. Henry [15] Over the past decade several literatures have shown that there is a lack of geographical knowledge among students. This requires a focus for the development of strong geographical literacy. Even though if we study geography more deeply and broadly, it can be interpreted that geography literacy is important for students to have especially with mastering five fundamental concepts, namely location, human-environmental relations, movement, and region [16]. Henry [15] explained that geography literacy is very important because with the better geography literacy, it will be able to see meaning in the arrangement of things in space and the ability to apply spatial perspectives to life situations.

Therefore, it requires improvisation and innovation to package social studies learning that contains geographic content interestingly and is able to equip and train students' geography literacy in order to have a correct basic understanding of space (location). One way to realize this and at the same time answer the challenges of the Indonesian Revolution 4.0 in the field of learning by utilizing the use of e-learning based (Computer Supported Collaborative Learning (CSCL).

\section{$2 \quad$ Method}

The development of this learning innovation used the method of research and development $(\mathrm{RnD})$. It is a research that intentionally, systematically, aims or directed to find, formulate, improve, develop, produce, test the effectiveness of products, models, methods, strategies, ways, services, certain procedures that are superior, new, 
effective, efficient, productive, and meaningful [17]. Meanwhile, the model used in this development is the ASSURE model with the following steps.

\subsection{Analyze learner}

As a first step before the media is developed, it is necessary to analyze and identify the character of students. The purpose of this stage is to determine the urgent learning needs of students so that they are able to get the maximum level of knowledge in learning. The analysis included three factors, namely general characteristics, specific entry competencies, and learning style.

\subsection{States objectives}

This stage specifically formulates knowledge, skills, and attitudes as goals that must be mastered by students after participating in social studies learning activities.

\subsection{Select methods, media, and material}

a. Method: The choice of social studies learning strategies must be adjusted to the learning objectives. In addition, it must also pay attention to the learning modalities and motivation of students who can later support learning.

b. Media: Media refers to the type of media used in learning. Social studies learning that takes place utilizes the use of e-learning based on Computer Supported Collaborative Learning (CSCL).

c. Material: Learning material that will be developed and provided at the time of learning contains factual problems (in the form of cases, pictures, and facts) that are around the student environment. Learning material will be packaged in a learning module and uploaded as reading material, the material is discussed independently or in groups. Then, the results of the discussion will be discussed online through elearning.

\subsection{Utilize media and materials}

The module produced as an achievement target contains a description of the subject matter of geography and analytical practice questions to hone the geography literacy of students in solving problems that occur around them. This module will also be equipped with innovative video packages by taking interesting topics on the field. With the combination of these two things, it is expected that students will be able to have a concrete understanding of the phenomenon of geography studies. Developed media products have several advantages including easy access to be able, user friendly, community-based. 


\subsection{Require learner participation}

Utilization of e-learning based on Computer Supported Collaborative Learning (CSCL) in learning enables students to develop learning modes to construct their knowledge independently through communication results with their environment and applying the material they have learned. The creation of the independence of students to develop their personal capacity with a variety of CSCL is a basic capital in forming individuals who are able to adapt and are ready to learn to develop their skills whenever and wherever.

\subsection{Evaluate and revise}

After learning through e-learning media based on Computer Supported Collaborative Learning (CSCL) has been completed, an evaluation is needed to determine the effectiveness of its use in learning activities. To get a complete picture, it is necessary to evaluate both the process and the results.

Data were analyzed using the following formula.

Meanwhile, for product eligibility was based on the table below:

$\mathrm{P}=\frac{\sum x}{\sum x i} \times 100 \%$

Info: $\mathrm{P}=$ Percentage

$\sum x=$ Total response

$\sum x \mathrm{I}=$ Total Ideal answer

$100 \%=$ Constant number

Table 1. The Criteria for Instrument Eligibility

\begin{tabular}{|c|l|}
\hline Percentage (\%) & \multicolumn{1}{|c|}{ Information } \\
\hline $80-100$ & Very goog (No revision) \\
\hline $66-79$ & Good (Mayor revision) \\
\hline $56-65$ & Fair (Minor revision) \\
\hline $40-55$ & Poor (Revision and redesign material content) \\
\hline $0-39$ & Bad (Rejected) \\
\hline
\end{tabular}

Source: Arikunto [18].

\section{$3 \quad$ Result}

\subsection{Product specification}

The product developed is in the form of a Geography Basic Concept learning module and 3 video material uploaded through e-learning. The module is produced as an 
achievement target that contains a description of the subject matter of geography and analytical practice questions to hone students' ability to solve problems around them. This module, also equipped with innovative video packed with interesting topics sourced from field experience. This module is also expected that students can have a concrete understanding in the field of geography studies.

Learning design is expected to provide online learning experiences (e-learning). The concept of e-learning is intended as an effort to distribute learning materials through electronic media or the internet. With this, students can access it anytime from all corners of the world. Flexibility is the key word in this e-learning system. Students become very flexible in choosing the time and place of learning. They don't have to come somewhere at a certain time. On the other hand, teachers can update their learning material anytime and from anywhere. In terms of content, learning material can be made very flexible starting from text- based material to learning material that is loaded with multimedia components.

\subsection{Product description}

The product descriptions developed in the form of modules and videos integrated in e-learning are as follows.

1. Module: Modules contain material to learn basic concepts in geography. In total, this module contains 9 learning activities (fig 1), each of which contains material descriptions and analytical exercises to stimulate students' reasoning abilities. This module is equipped with interesting pictures (fig 1) to facilitate the learning capital of each student participant. In addition, this module is packaged into a single unit and provides opportunities for students to study the learning material as a whole.
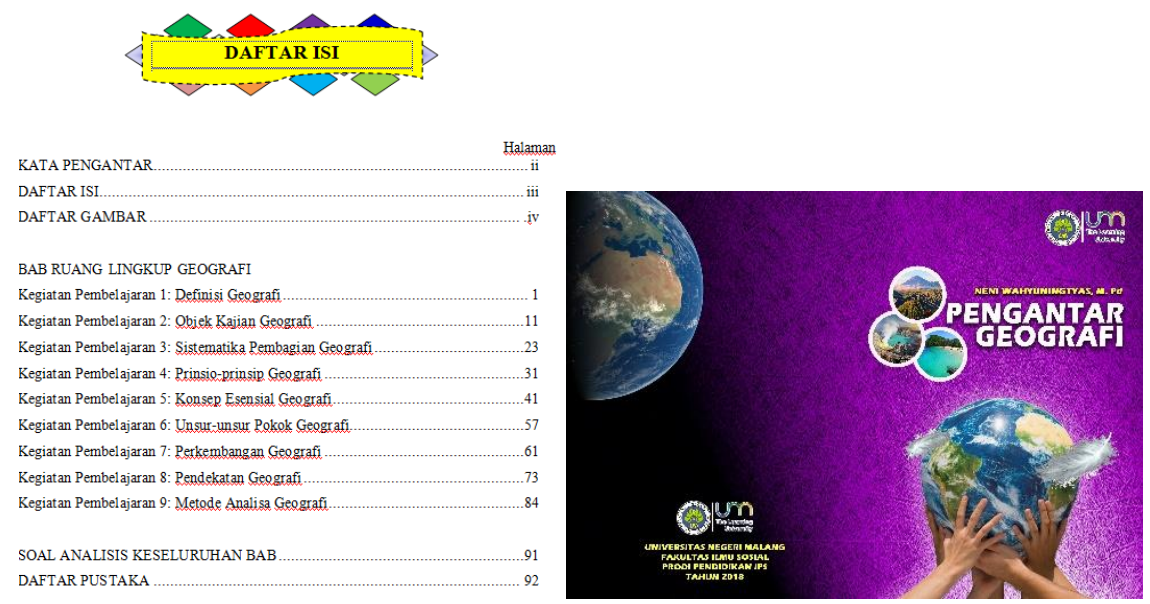

Fig. 1. Cover display

2. Videos: The video contains interesting topics in the field. The location of the video is on the southern slope of Mount Kelud in Blitar Regency which incidentally is 
the Natural Laboratory of FIS UM. Some of the contents of the video are also taken from youtube such as the phenomenon of the eruption of Mount Kelud. This is because the eruption process had occurred in the previous year and the developer wanted to give a concrete and complete picture of the eruption process of Kelud and its influence on the lives of Blitar District residents. Innovative video packaged by combining animation and interesting effects.

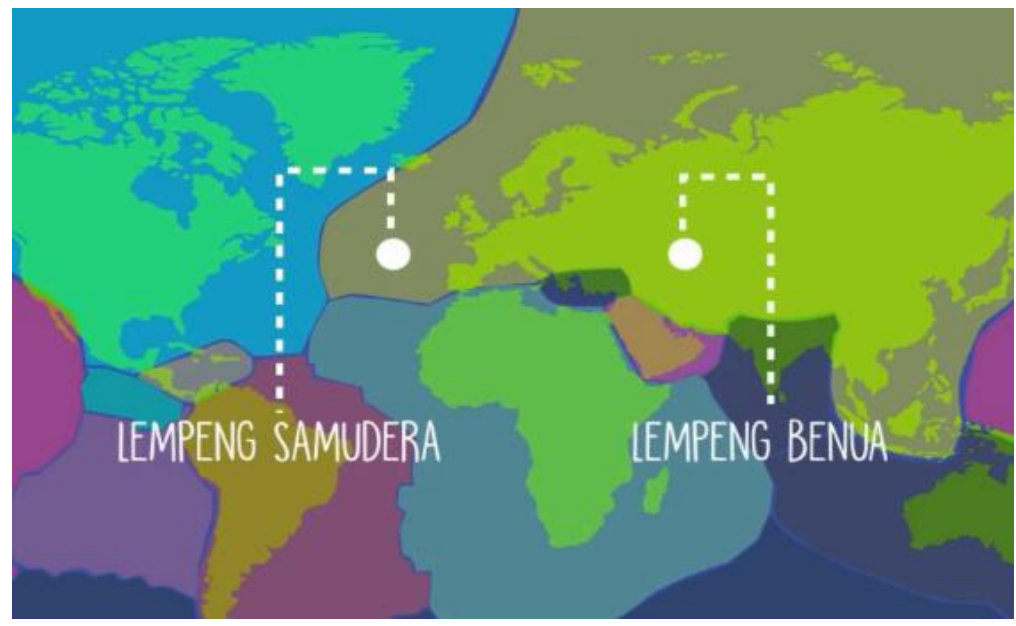

Fig. 2. Animated display in Video

Both products are packaged in such a way through e-learning that will later be used in online-based regular learning. The module and video products should be integrated into the UM E-learning application, but because the application is still in the arrangement, it is transferred to other applications such as edmodo. The example display as follows in fig 3:

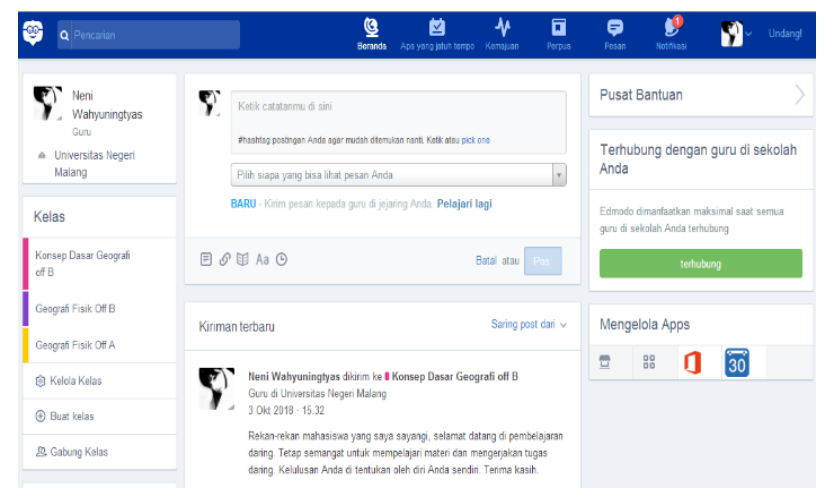

Fig. 3. E-learning display 


\subsection{The result of validation}

1. Media: Media product validation was assessed by an expert validator, Syaiful Amin, M.Pd. He is a lecturer in the Department of Social Studies, Faculty of Tarbiyah UIN Maliki Malang who is concerned with learning media. The results of this learning media validation are as follows in table 2.

Table 2. The Details of Media Validation Result

\begin{tabular}{|c|c|c|c|c|c|}
\hline \multirow{2}{*}{ No } & \multirow{2}{*}{ Evaluation criteria } & \multicolumn{4}{|c|}{ Score } \\
\hline & & 1 & 2 & 3 & 4 \\
\hline \multirow{7}{*}{1} & Media Display: & & & & \\
\hline & Interesting display & - & - & - & $\mathrm{V}$ \\
\hline & The use of background & - & - & - & V \\
\hline & The use of colours combination & - & - & $\mathrm{V}$ & - \\
\hline & The font clearance & - & - & - & $\mathrm{V}$ \\
\hline & Language usage & - & - & - & $\mathrm{V}$ \\
\hline & Media size appropriateness & - & - & $\mathrm{V}$ & - \\
\hline \multirow{4}{*}{2} & Material Display: & & & & \\
\hline & Clarity of presented material & - & - & - & $\mathrm{V}$ \\
\hline & Easy of understanding & - & - & $\mathrm{V}$ & - \\
\hline & The breadth and depth of presented material & - & - & $\mathrm{V}$ & - \\
\hline \multirow{6}{*}{3} & Contents: & & & & \\
\hline & Conformity of indicators with basic competencies & - & - & $\mathrm{V}$ & - \\
\hline & The material suitability with the indicators & - & - & $\mathrm{V}$ & - \\
\hline & The matching of material appearance & - & - & $\mathrm{V}$ & - \\
\hline & The accuracy of material concept & - & - & - & $\mathrm{V}$ \\
\hline & Compatibility of content display & - & - & - & $\mathrm{V}$ \\
\hline \multirow{4}{*}{4} & Figures and Tools: & & & & \\
\hline & Clarity of image display & - & - & $\mathrm{V}$ & - \\
\hline & Clarity of image meaning & - & - & - & $\mathrm{V}$ \\
\hline & Interesting image & - & - & - & $\mathrm{V}$ \\
\hline
\end{tabular}

Table 3. Media Validation

\begin{tabular}{|c|c|c|c|c|c|c|c|c|c|c|c|c|c|c|c|c|c|c|}
\hline \multirow{2}{*}{ Media Validator } & \multicolumn{10}{|c|}{ Questions } \\
\cline { 2 - 17 } & $\mathbf{1}$ & $\mathbf{2}$ & $\mathbf{3}$ & $\mathbf{4}$ & $\mathbf{5}$ & $\mathbf{6}$ & $\mathbf{7}$ & $\mathbf{8}$ & $\mathbf{9}$ & $\mathbf{1 0}$ & $\mathbf{1 1}$ & $\mathbf{1 2}$ & $\mathbf{1 3}$ & $\mathbf{1 4}$ & $\mathbf{1 5}$ & $\mathbf{1 6}$ & $\mathbf{1 7}$ & \\
\hline 1 & 4 & 4 & 3 & 4 & 4 & 3 & 4 & 3 & 3 & 3 & 3 & 3 & 4 & 4 & 3 & 4 & 4 & 60 \\
\hline & \multicolumn{10}{|l}{ Total Ideal Score } \\
\hline
\end{tabular}

To calculate the percentage level, the following formula can be used.

$$
\mathrm{P}=\frac{\sum x}{\sum x i} \times 100 \%
$$

It can be seen that the percentage of quantitative data from the first validation results is as follows: 


$$
\begin{gathered}
\mathrm{P}=\frac{60}{68} \times 100 \% \\
\mathrm{P}=88,24
\end{gathered}
$$

The results of the product feasibility analysis amounted to 88.24. This can be concluded that the media in this development are classified as very good and do not need to be revised. However, to get a better product quality, the developer still revised some of the input from the validator.

2. Materials: The next step is to validate the material. This validation aims to assess whether the material developed has been appropriate and in accordance with existing rules and concepts or not. The material validator is Ninja Panju Purwita, M. Pd. He is a lecturer who teaches at the Department of Social Studies at the Faculty of Tarbiyah UIN Maliki Malang. Based on the results of the validator assessment, the following results were obtained:

Table 4. The Details of Materials Validation Result

\begin{tabular}{|c|l|c|c|c|c|}
\hline \multirow{2}{*}{ No } & \multicolumn{1}{|c|}{ Learning Aspect } & \multicolumn{3}{c|}{ Score } \\
\cline { 3 - 5 } & & \multicolumn{1}{|c|}{$\mathbf{I}$} & $\mathbf{2}$ & $\mathbf{3}$ & $\mathbf{4}$ \\
\hline 1 & $\begin{array}{l}\text { The suitability of the material with basic } \\
\text { competencies }\end{array}$ & - & - & - & V \\
\hline 2 & The suitability of the material with the indicator & - & - & - & V \\
\hline 3 & $\begin{array}{l}\text { The suitability of the material with the learning } \\
\text { objectives }\end{array}$ & - & - & - & V \\
\hline 4 & Student interactivity with the media & - & - & - & V \\
\hline 5 & Triggering learning motivation & - & - & V & - \\
\hline 6 & The actuality of materials presented & - & - & - & V \\
\hline 7 & Easy to understand & - & - & V & - \\
\hline 8 & The flow of thought & - & - & V & - \\
\hline 9 & The Clarity of material description & - & - & - & V \\
\hline 10 & The appropriateness of terms and statement usage & - & - & V & - \\
\hline
\end{tabular}

Table 5. Tabulation of Material Validation

\begin{tabular}{|c|c|c|c|c|c|c|c|c|c|c|c|}
\hline Materials Validator & \multicolumn{9}{|c|}{ Questions } & \multirow{2}{*}{ Score } \\
\cline { 2 - 13 } & $\mathbf{1}$ & $\mathbf{2}$ & $\mathbf{3}$ & $\mathbf{4}$ & $\mathbf{5}$ & $\mathbf{6}$ & $\mathbf{7}$ & $\mathbf{8}$ & $\mathbf{9}$ & $\mathbf{1 0}$ & \\
\hline 1 & 4 & 4 & 4 & 4 & 3 & 4 & 3 & 3 & 4 & 3 & 36 \\
\hline & \multicolumn{9}{|l}{ Total of Ideal Score } \\
\hline
\end{tabular}

To calculate the percentage level, the same formula, for media validation, can be used and the result indicates as follow:

$$
\begin{gathered}
\mathrm{P}=\frac{36}{40} \times 100 \% \\
\mathrm{P}=90
\end{gathered}
$$

The results show that the percentage of material validation has a value of 90 . Based on the product feasibility analysis table, it is concluded that the product is very good and no revision. 


\subsection{Implementation}

The product was tested on 8 students of class of 2017, a social studies education program. This trial is used to determine student responses to the learning media developed. The results show as follows:

Table 6. The Student Response

\begin{tabular}{|c|c|c|c|c|c|c|c|c|c|c|c|c|}
\hline \multirow{2}{*}{$\begin{array}{c}\text { No. } \\
\text { Respondents }\end{array}$} & \multicolumn{11}{|c|}{ Questions } & \multirow{2}{*}{ Total } \\
\hline & 1 & 2 & 3 & 4 & 5 & 6 & 7 & 8 & 9 & 10 & 11 & \\
\hline 1 & 4 & 3 & 4 & 4 & 4 & 4 & 4 & 4 & 4 & 4 & 4 & 43 \\
\hline 2 & 3 & 3 & 4 & 3 & 2 & 3 & 4 & 4 & 2 & 2 & 4 & 34 \\
\hline 3 & 4 & 3 & 4 & 3 & 4 & 4 & 3 & 3 & 3 & 2 & 3 & 36 \\
\hline 4 & 3 & 3 & 3 & 4 & 2 & 2 & 3 & 3 & 4 & 2 & 2 & 31 \\
\hline 5 & 3 & 3 & 4 & 3 & 3 & 4 & 3 & 3 & 4 & 3 & 4 & 37 \\
\hline 6 & 4 & 4 & 4 & 4 & 3 & 3 & 3 & 3 & 4 & 3 & 4 & 39 \\
\hline 7 & 3 & 3 & 4 & 3 & 3 & 3 & 4 & 3 & 3 & 3 & 4 & 36 \\
\hline 8 & 3 & 2 & 3 & 3 & 2 & 3 & 3 & 3 & 3 & 3 & 3 & 31 \\
\hline Total & 27 & 24 & 30 & 27 & 23 & 26 & 27 & 26 & 27 & 22 & 28 & 287 \\
\hline Total Score & \multicolumn{4}{|c|}{108} & \multicolumn{4}{|c|}{102} & \multicolumn{3}{|c|}{77} & 287 \\
\hline $\begin{array}{l}\text { Total of Ideal } \\
\text { Score }\end{array}$ & \multicolumn{4}{|c|}{128} & \multicolumn{4}{|c|}{128} & \multicolumn{3}{|c|}{96} & 352 \\
\hline
\end{tabular}

The percentage was calculated based on the same formula to examine the validation. The result shows as follow.

Table 7. The Result of Eligibility

\begin{tabular}{|c|c|c|}
\hline $\begin{array}{c}\text { Learning Media } \\
\text { Attractiveness }\end{array}$ & $\begin{array}{c}\text { Learning Media } \\
\text { Efficiency }\end{array}$ & $\begin{array}{c}\text { Learning Media } \\
\text { Effectivity }\end{array}$ \\
\hline $\mathrm{P}=\frac{108}{128} \times 100 \%$ & $\mathrm{P}=\frac{108}{128} \times 100 \%$ & $\mathrm{P}=\frac{77}{96} \times 100 \%$ \\
$\mathrm{P}=0,843 \times 100$ & $\mathrm{P}=0,796 \times 100$ & $\mathrm{P}=0,802 \times 100$ \\
$\mathrm{P}=84$ & $\mathrm{P}=80$ & $\mathrm{P}=80$ \\
\hline
\end{tabular}

Table 7 shows that for the eligibility of the product based on aspects of media attractiveness (84), efficiency (80), and effectiveness (80), in general, has a good value category. This means that the product is eligible as a learning medium based on each criterion. To conclude that this product can be used as a learning medium, it is also necessary to calculate all values from each criterion as follows.

$$
\begin{gathered}
\mathrm{P}=\frac{287}{352} x 100 \% \\
\mathrm{P}=0,815 \times 100 \\
\mathrm{P}=82
\end{gathered}
$$


The calculation results show that the product's feasibility value is 82 . This means the results of the implementation with the indicators of attractiveness, efficiency and effectiveness, are declared to be very good and this media is eligible as a learning medium.

\subsection{Discussion}

The Computer Supported Collaborative Learning (CSCL) learning model is part of the learning process with a student-centered learning model. CSCL is an interesting learning approach and is in accordance with modern learning concepts. The paradigm of modern education is to make educators not merely transferring knowledge, but rather as facilitators and motivators. This CSCL learning model is formed from a combination of cooperative learning models and the use of computers and the internet as a medium in learning. For adaptation to technological advances and digital life to be a necessity, CSCL learning models should be further utilized and developed.

CSCL-based learning is able to shape students 'self-reliance and sense of responsibility, increase students' learning motivation, build critical thinking skills of students in problem solving, and be able to make students build their own knowledge [19]. The CSCL model also offers a non-traditional learning innovation in the design and delivery of non-monotonous material focused on memorization. Wahyuningtyas, et al. [20] indicated that the varied learning and arousing motivation and interest of students is needed in the Industrial Revolution 4.0. Learning with CSCL will provide new variations and new learning experiences for students, where students can interact with each other in a learning structure designed by teachers to create more collaborative exploration and discussion situations [21].

CSCL offers an innovation and advantage over the use of computer technology in the learning model. Panitz in Robert [22] revealed that the benefits of the CSCL model were seen from academic, social, and psychology. The academic benefits that can be obtained by collaborative learning are increasing student critical thinking, the activeness, and learning outcomes. Furthermore, the social benefits consist of fostering social attitudes of students, especially with other students in the learning process, building togetherness and understanding differences between students, forming a positive atmosphere of togetherness and mutual assistance between students. In addition, this model also psychologically can increase student self-esteem and develop their positive attitude before the teacher or lecturer.

The implementation of the CSCL model can minimize learning by memorizing. The material learned is also easily understood by students. The material is not the main material that must be presented by educators, but it should originate from students' own understanding. Educators will only be facilitators and motivators for students. With the increasingly effective CSCL-based learning, this course will be positively correlated with student learning outcomes. Wahyuningtyas and Rosita [23] indicate that the use of innovative and innovative learning media is one of the factors that can motivate students to learn and be able to encourage them to achieve maximum learning outcomes. 


\section{Conclusion}

The use of interactive multimedia based on Computer Supported Collaborative Learning (CSCL) with the integration of modules and videos that are in it arouse the motivation and effectiveness of student learning processes. With the implementation of this media, students gain new learning experiences, where students can interact with each other in a learning structure designed by the instructor to create a more collaborative and interesting exploration and discussion situation.

\section{$5 \quad$ References}

[1] B. Kurniawan, I. Idris, A. Purnomo, A. Wiradimadja, and S. Sukamto, "Using Broadcasting Learning Design to Enhance Student's Experiential Skill," Int. J. Emerg. Technol. Learn. IJET, vol. 14, no. 16, pp. 172-180, Aug. 2019. https://doi.org/10.3991/ijet.v14i16.10652

[2] W. D. Sulistyo, U. Nafi'ah, and I. Idris, "The Development of E-PAS Based on Massive Open Online Courses (MOOC) on Local History Materials," Int. J. Emerg. Technol. Learn. IJET, vol. 14, no. 09, p. 119, May 2019. https://doi.org/10.3991/ijet.v14i09.10143

[3] I. K. Suartama, P. Setyosari, S. Sulthoni, and S. Ulfa, "Development of an Instructional Design Model for Mobile Blended Learning in Higher Education," Int. J. Emerg. Technol. Learn. IJET, vol. 14, no. 16, p. 4, Aug. 2019. https://doi.org/10.3991/ijet.v14i16.10633

[4] J. Khlaisang and K. Mingsiritham, "Engaging Virtual Learning Environment System to Enhance Communication and Collaboration Skills among ASEAN Higher Education Learners," Int. J. Emerg. Technol. Learn. IJET, vol. 11, no. 04, p. 103, Apr. 2016. https://doi.org/10.3991/ijet.v11i04.5503

[5] I. Idris, "Exploring organizational culture, quality assurance, and performance in higher education," Manag. Econ. J. MEC-J, vol. 3, no. 2, pp. 166-181, 2019. https://doi.org/10.188 60/mec-j.v3i2.7529

[6] I. Idris and K. R. Adi, "Transformational Leadership and Team Performance: The Role of Innovation in Indonesia Property Agent Industry," in Proceedings of the 2018 International Conference on Islamic Economics and Business (ICONIES 2018), Kota Malang, Indonesia, 2019, pp. 334-338. https://doi.org/10.2991/iconies-18.2019.67

[7] A. Sani, I. S. Wekke, V. M. Ekowati, B. Abbas, and I. Idris, "Moderation effect of workplace spirituality on the organizational citizenship behavior," Int. J. Appl. Bus. Econ. Res., vol. 16, no. 2, pp. 455-465, 2018.

[8] A. Sani, VM. Ekowati, I. S. Wekke, and I. Idris, "Respective contribution of entrepreneurial leadership through organizational citizenship behavior In creating employees performance," Acad. Entrep. J., vol. 24, no. 4, pp. 1-11, 2018.

[9] S. Abou El-Seoud, N. Seddiek, I. Taj-Eddin, P. Ghenghesh, A. Nosseir, and M. El-Khouly, "E-Learning and Students' Motivation: A Research Study on the Effect of E-Learning on Higher Education," Int. J. Emerg. Technol. Learn. IJET, vol. 9, no. 4, p. 20, Jun. 2014. https://doi.org/10.3991/ijet.v9i4.3465

[10] M. Abbad and F. Jaber, "Evaluating E-Learning Systems: An Empirical Investigation on Students' Perception in Higher Education Area," Int. J. Emerg. Technol. Learn. IJET, vol. 9, no. 4, p. 27, Jun. 2014. https://doi.org/10.3991/ijet.v9i4.3480

[11] R. D. Johnson, S. Hornik, and E. Salas, "An empirical examination of factors contributing to the creation of successful e-learning environments," Int. J. Hum. Comput. Stud., vol. 66, no. 5, pp. 356-369, May 2008. https://doi.org/10.1016/j.ijhcs.2007.11.003 
[12] I. M. Romi, "A Model for e-Learning System Success: Systems, Determinants, and Performance," Int. J. Emerg. Technol. Learn. IJET, vol. 12, no. 10, pp. 4-20, 2017. https://doi.org/10.3991/ijet.v12i10.6680

[13] M. Farah, G. Ireson, and R. Richards, "A Content, Pedagogy and Technology [CPT] Approach to TPACK," Imp. J. Interdiscip. Res., vol. 2, no. 12, pp. 1162-1170, 2016.

[14] D. Xinyu and Li Min, "Design of Computer Supported Collaborative Learning System Based on Learning Contract," in IEEE Computer Society, USA, 2008, vol. 08, pp. 181-184. https://doi.org/10.1109/ICCEE.2008.129

[15] H. Praherdhiono, E. P. Adi, and Y. Prihatmoko, "Konstruksi demokrasi belajar berbasis kehidupan pada implementasi LMS dan MOOC," Edcomtech, vol. 3, no. 1, pp. 21-28, 2018.

[16] E. Maryani, Pengantar Geografi Perkotaan. Bandung: Jurdik Geografi Universitas Pendidikan Indonesia, 2002.

[17] N. Putra, Research \& Development "Penelitian dan Pengembangan: Suatu Pengantar". Jakarta: PT. Raja Grafindo Persada, 2012.

[18] S. Arikunto, Prosedur Penelitian: Suatu Pendekatan Praktik. Jakarta: Rineka Cipta, 2014.

[19] E. Satria, "Model Pembelajaran Computer Support Collaborative Learning (CSCL)," Thesis, Universitas Neger Yogyakarta, Yogyakarta, 2009.

[20] N. Wahyuningtyas, "Developing Edmodo-Based Online Learning Media to Support Student's Skill Of Social Studies In 21th Century," in IOP Conference Series: Earth and Environmental Science, Jember, 2019, vol. 243, p. 012160. https://doi.org/10.1088/1755$\underline{1315 / 243 / 1 / 012160}$

[21] Purnamawati and H. Jaya, "Pengembangan Model Pembelajaran Kolaboratif melalui Pendekatan CSCL (Computer Supported Collaborative Learning) pada Fakultas Teknik Universitas Negeri Makassar," J. MEKOM Media Komun. Pendidik. Kejuru., vol. 3, no. 2, pp. 167-185, 2016.

[22] T. S. Robert, Computer-Supported Collaborative Learning in Higher Education. USA: Idea Grup Publishing, 2005. https://doi.org/10.4018/978-1-59140-408-8

[23] N. Wahyuningtyas and F. A. D. Rosita, "Pengembangan Multimedia Interaktif Berbasis Android pada Materi Kehidupan Sosial Masyarakat Indonesia," Sej. Dan Budaya J. Sej. Budaya Dan Pengajarannya, vol. 13, no. 1, pp. 34-41, Jun. 2019. https://doi.org/10. 17977/um020v13i12019p034

\section{Authors}

Idris is one of the lecturers in Social Studies Program, Faculty of Social Science, Universitas Negeri Malang. $\mathrm{He}$ is interested in learning innovation. Email: idris.fis@um.ac.id

Neni Wahyuningtyas is a lecturer in Faculty of Social Science, Universitas Negeri Malang, Indonesia. She is majoring in Geography and mastering in learning media and related information technology in education. Email: neni.wahyuningtyas.fis@um.ac.id

Article submitted 2020-01-19. Resubmitted 2020-02-24. Final acceptance 2020-02-27. Final version published as submitted by the authors. 